\title{
Travesty of Life Elders Abuse an Inquiry of Physical and Psychological Abuse
}

\author{
Naval Bajpai ${ }^{1} \cdot K_{\text {Kushagra Kulshreshtha }}{ }^{2}$ Prince Dubey ${ }^{2} \cdot$ Gunjan Sharma $^{2}$
}

Accepted: 21 December 2021

(C) The Author(s), under exclusive licence to Springer Science+Business Media, LLC, part of Springer Nature 2022

\begin{abstract}
Elder abuse is evil in human society. The present paper unveils this social issue from two major factors psychological and physical abuse. The study sensitizes the subject matter of study by examining the effects of demographic variables like gender and age on elders. For achieving the purpose of the study the research is a design by exploring and validating the factors of measuring elder abuse through the mix method approach, exploratory factor analysis (EFA) and confirmatory factor analysis (CFA). To test the established hypotheses of the effects of the demographic variable on elders the two-way ANOVA was applied. The present study verdicts the development of a sound measurement scale with two influence factors. The separate and composite effect of aging and gender type on elder abuse was evidenced. These findings are crucial especially when the prevalence of elder abuse is higher during COVID-19. The limited novel understudied variable opens an avenue for further research in behavioral and demographic variables like marital status. The present study has practical insinuation for caring the elders in any human society like physical and psychological treatment of elders to avoid abusive situations. In addition, the study attempts to validate the novel issues like psychological and physical abuse of elders in the dimensions of demographic variables. Some rare studies in the Indian continent established the motivation of conducting the research on this dimension.
\end{abstract}

Keywords Elder abuse $\cdot$ Society $\cdot$ Social problem $\cdot$ Social isolation $\cdot$ Psychological abuse $\cdot$ Physical abuse

Kushagra Kulshreshtha

kushagra.kulshrestha@gla.ac.in

1 ABV-Indian Institute of Information Technology and Management (ABV-IIITM), Gwalior, MP, India

2 Institute of Business Management, GLA University, Mathura-281406 (U.P), India 


\section{Introduction}

Cited in the US Congress (1990, p10), Pearl Sydenstricker Buck, the first female American Nobel Laureate quoted:

"Our society must make it right and possible for old people not to fear the young or be deserted by them, for the test of a civilization is the way that it cares for its helpless members."

For achieving the aforesaid thought, the older adults need care and support in place of neglect and abuse. The older adults of this era are living longer than ever, just thanks to the advancement in the medical science, technology and consciousness about the nutritious diet to them (Wheeler, 2010). As per WHO, approximately 15.7 percent older generation 60 years and above were subject to some form of abuse (WHO, 2021). In community as well as institution setting, the prevalence of different forms of elder abuse has increased during COVID-19 up to 83.6 percent (Chang \& Levy, 2021a, 2021b). Moreover, the victims of elder abuse have higher chances to die prematurely (Lachs et al., 1998). As predicted, the older population (60 years), is going to be 2 billion by 2050, then the older age victims will reach to 320 million (WHO, 2021). The irony is that only 1 out of 24 cases are being reported due to some or other reasons. This means the cases are underreported and thus the situation is underestimated. India having a high population density is also not spared from elder abuse. HelpAge India, an organisation for social causes reported that in 2014 approximately 50 percent of older adults surveyed were the victim of elder abuse. Nationally, 77 percent youth admitted the presence of elder abuse, they also (83 percent) feel that presence of elder abuse in the neighborhood is no surprise (HelpAge India, 2017). In 2009, the population of older adults in India was $7 \%$ and by 2050, it would grow up to $20 \%$ (Census of India, 2011). In old age, persons require a support system that provides some level of mental support and care. This becomes imperative because most elderly suffer from some age related diseases (Reinhard et al., 2008). In this context, caregiving is necessary for an older adults and can be provided in two ways, the 'informal care' by his/her family members and 'formal care' by a healthcare professional at home or in a nursing home (Donelan et al., 2002). The demanding behavior of older adults and the burden of caregiving put older adults in the risk of rude behavior from his/her caregivers (Miller et al., 2006; Silver et al., 2004). The caregiver's behavior can cause physical and psychological harms to elders. Here, psychological abuse is one of the invisible abuse types. However, it has no physical indicators and thus difficult to identify. It may be exercised through verbal or nonverbal means (Traxler, 2017). On other hand, physical abuse is about causing harm to the body of older adults. Under physical abuse, annoyance to the body causing the pain or serious or less serious injury, physical compulsion or drug-induced restraint is caused (Paul \& Parkins, 2017). The issue of elder abuse has become a matter of more concern in the present pandemic i.e. COVID-19. While exploring the relationship between elder abuse and COVID-19, we came across with an interesting term pandemic paradox i.e. during pandemic when people are advised 
to stay at home considering it being safe is actually not, when men or women at home are in abusive relationship (Bradbury-Jones \& Isham, 2020). The domestic violence cases were tripled then before and the same is also significantly affecting elders' status as the preparatory and the victim (older adults) are staying for longer hours at same premises (Graham-Harrison et al., 2020). On the other side, during pandemic, staying alone may also give rise to social isolation, high consumption of alcohol and put the person at the risk of elder abuse such as financial fraud and even the serious health issues and premature death chances also get double (Centers for Disease Control \& Prevention, 2021; Singer, 2018). Before pandemic, one out of tenth American older adult reported elder abuse, and during pandemic this reached to one out of five older people (Chang \& Levy, 2021a, 2021b; Naughton et al., 2021). During pandemic the financial resources are depleting rapidly resulting in increased stress on caregiver or other family members more than ever. Second, the presence of the preparatory and the elder at same place might make the situation worse (ibid). In fact, all the factors that give rise to elder abuse have been compounded during COVID-19 restrictions. Thus, it seems that elder abuse cases are rampant during COVID-19. Therefore, exploring the different dimensions of elder abuse has become imperative for the benefit of older adults, caregivers, society, social workers and policy makers.

The present study sensitizes the issue of abusive behavior in the context of elders. The works dealt with the varied behavior accountable for elder's abuse in the form of psychological and physical issues. The detailed exploration of incepted idea through related studies will formalize the research insights followed by methodology and discussion on selected demographical variables for novel dimension in improving the elder abuse prevalence in India.

The structure of the paper consists: (i) literature review (ii) methodology (iii) results and discussion (iv) conclusion (v) implications and (vi) limitation and scope of future research.

\section{Literature Review}

The concept or a phenomenon of elder abuse resides on variety of factors. The present study casted the theoretical and statistical relationship of psychological and physical abuse as factors to describe the elder abuse as follows:

\section{Psychological Abuse}

The psychological abuse is one of the types of abusive behavior affecting elder people (WHO, 2002; WHO, 2011). Several researchers attempted to define psychological abuse as the destructive action, mental torture or derailment of mind or suffering from an emotional situation such as harassment, threats, humiliation, or intimidation, attack on self-esteem or sense of safety of the person by another (Comijs et al., 1998; Follingstad \& Dehart, 2000; Mezey et al., 2002; O'Leary, 1999). Psychological abuse is the deliberate infliction of the mental or emotional suffering of 
humiliation, threat, or other verbal/nonverbal conduct (Senior Rights, 2020). Under psychological abuse due to the verbal and non-verbal acts person feels mental pain, anguish, stress, headache or agony (Iborra, 2008; Astin et al., 1993). Consequently, the changes seen in the behavior of the older adults may also be an indicator of the psychological abuse (Quinn \& Tomito, 1986) tough the identification is quite difficult. Thus, for understanding the psychological abuse, various theoretical models were proposed by several researchers having reliance upon the interpersonal (relationships, tendency), personal characteristics (age, gender, habits) of the victim (elder) and the abuser (a caregiver or family member) (Cunningham, 1998), while some focused on socio-cultural factors (Hammer, 2001). The intervention of psychological abuse was explained by two approaches: firstly, 'effects-based approaches', that "tend to identify the range of harm experienced by victims ranging from low self-esteem, self-harming behaviors, anxiety, chronic stress, phobia, insomnia, and nightmares, to posttraumatic stress, depression, and suicidal thoughts" and second is 'behavior-based approaches' 'identify tactics' or 'red flag' behaviors of abusers (Hamarman \& Bernet, 2000). To label any behavior as psychological abuse, the abuser must be observed for his/her intention, sustained and repeated patterns of behaviors and responses (Hamarman \& Bernet, 2000).

Building upon the above context, India is growing more in terms of aging (Talpur et al., 2018). It may be good for the individuals and for their family members, but at the same time longevity of elder also attracts economic, social, health challenges and dependency (physically, mentally and financially) over others (Govil \& Gupta, 2016; Jamshidi et al., 1992). Longevity of the elder person in the family with functional impairment need a constant care (World Health Organization, 1999). Generally, family member provides health care to the older adults, knowing that the family dynamics is significant to understand and maintain cordial relation between the caregiver family members and the older adults (Goncalves et al., 2011). It is worth noticing that the family is like an interconnected social sub-system, and gender and aging of a person can affect the family dynamics (Margaret, 1997). There is a possibility of infinite combination of transformation dynamics in attitude and culture due to interaction under family subsystems of spousal (husband-wife), parental (parent-child), fraternal (child-child) and familial setup (nuclear family interactions with an external individual). These dynamics can be evident as strong bonded and loving families take the mutual decision over the education, career planning and overall development of children (Lafortune, 2014). Providing care and assistance to the aging elders develops normative stress and invisible social problem among all family members leading to maltreatment i.e. abuse (Kosberg, 1990; Kosberg \& Garcia, 1995). The elder living in the overcrowded family arrangement with gender difference creates inter-generational conflicts (crisis) transmuting into sibling rivalry for years (Anderson, 2017; Kosberg, 1988). Such rivalry becomes the routine part of the family and none wants to take additional burden of caring affecting elders emotionally and eventually leading to isolation (Tewari, 2009).

A proper and constant caregiving to elders is toughest and painful work requires a dedication and energy (Smith \& King, 2002). Constant caring needs an ability of continuous efforts to fulfill raising demands and sometimes elder's own tendency of 
verbal or physical aggression develops anxiety and depression causing ill behavior (scold or yelled) or a risk of emotional abuse (Hill, 2017; Reinhard et al., 2008). Such behavior is an indicator of low self-esteem indicators/ risk factors for poor quality care effecting elders psychologically varied based on their age and gender (Homer \& Gilleard, 1990; Miller, 2003; Williamson \& Shaffer, 2001) while caregiver balances the burden of caring and personal life by drink, drug or substance use (Beach et al., 2005; Pillemer \& Suitor, 1992).

The caregiving needs adequate knowledge of delivering proper care and assistance for older adults' activities of daily living (ADLs) (Bucher et al., 2001; Scherbring, 2002; Schumacher et al., 2000). However, the caregiver (informal) remains unfamiliar with the use of resources and the amount of care (Given et al., 1994). Consequently, elders are shifted to hospital or nursing home or a nurse at home; for medical administration such as medicine/tablets, injections, inhalers, and wheelchair (Sheridan, 2016; Travis et al., 2000). These situations prevail as caregiver declines or rejects the emotional support/dimensions towards the elders intentionally or unintentionally (Levine, 1998). Some dialogues in social setting were observed in common, 'I do not have a time for it', 'I have no authority for doing this', 'I do not have a sufficient amount of money to do this' etc. (Bursack, 2012).

In old age, being powerlessness i.e. a feeling of no control, or a sense of having no substantial effect on a consequence is often ignored by the researchers (Dryer, 2007; Kubsch \& Wichowski, 1997). Wilkinson (2005) defined powerlessness as "the perception that one's own action will not significantly affect an outcome; a perceived lack of control over a current situation or immediate happening" (pp. 386). Therefore, powerlessness can be considered as de-motivating factors (Craven \& Hirnle, 2003). Consequently, feelings of powerlessness persuade the elders loosing hope, and forces them to be dependent on caregiver (Salarvand et al., 2007).

In present modern era, the elders are found lonely in their home as caregiver are supposed to deal with the office assignments or might be staying at some other place and not able to visit due to pandemic or certain other restrictions (Horgas \& Abowd, 2004; Levine et al., 2003). Elders expects to receive care and assistance from caregivers at their best for peace of mind (Reinhard et al., 2008; Schumacher et al., 1999). Due to expectation disconfirmation, the elders feel anger, frustrations, hurt and envy towards caregiver (Spillman \& Pezzin, 2000). These feeling on being overt, the caregiver defend himself by thinking elders as burden (Carl, 2015; Scherbring, 2002). These conflicts, tensions, and disagreements in the family and their members force male or female elders divergently to get separated due to emotional imbalance (Matthiessen, 2017).

\section{Physical Abuse}

The National Centre on Elder Abuse and National Research Council (2003) defines physical abuse as the infliction of physical pain, injury, physical coercion, and involves at least one act of violence including beating, slapping, hitting, burning, cutting, or physical restraint, or intentional overmedication affecting the children and the older person in comparison to young adult (Barrett et al., 2009; Friedman et al., 2015; Mouton et al., 2005). This category of abuse refers to body actions 
carried out by younger one/caregiver with the intention of causing physical pain or injury to a (vulnerable) elder person. The examples of physical abuse may include being pushed, grabbed, stabbed, slapped, hit or strike with an object (World Health Organization, 2002).

A person living with the partner or the family members experience more physical abuse than who live in isolation (Podnieks, 2008). Social isolation is an important factor for violent situations and demented older adults often experience higher rates of physical abuse. Physical abuse is overt, evident more in police cases and psychiatric services when elders and caregiver live together with less privacy creating conflicts, misunderstanding and tension whereas neglect and emotional abuse is covert which can be observed, but generally not reported (Acierno et al., 2010; Bennet \& Kingston, 1993; Wang et al., 2006; Yan \& Kwok, 2011).

Generally, the cases of elder abuse are under-report or unreported (Broyles, 2000; Tatara, 1990). This may be because mostly older adult victim feels that complaining is pointless or useless, and he/she have fear of revenge by the abuser, or even some elders believed that they did not find anything abusive (Bowers et al., 2003; Pettee, 1997; Wolf, 1988). Even a family member could not recognize the abuse under the nursing home or hospital and becomes another reason of underreporting (Burgess et al., 2000; Pillemer \& Finkelhor, 1988; Ramsey et al., 2007). According to a report, $59.47 \%$ of elder persons in India filed a complaint against the abuse while remaining $40.53 \%$ did not report about the physical abuse that they faced at home or a nursing home/hospital (HelpAge India, 2014). This situation exists in spite of the having mechanisms of abuse redressal such as 24-h Police helpline number, HelpAge India helpline (an organization) number and other non-government organization (NGO) under the 'Welfare of parents and Senior Citizen Act 2007' (Govil \& Gupta, 2016; National Crime Records Bureau, 2014; HelpAge India, 2014).

\section{Aging and Elder Abuse}

Aging is a natural and inevitable phenomenon (Asti \& Erdem, 2006). Corresponding to this increase of the aging population in the world, the older adults faces impairment be it cognitive or/and physical and the chances of abuse against elders' also increases. It has been observed that persistent 'elder abuse' result in not only physical and psychological distress but also reduces overall quality of like, self-confidence, self-esteem, autonomy and alike (W.L. Lai et al., 2014). The ageing makes elders weak as metabolic activity of the body diminishing and required energy for body start decreasing. The emphasis on aging and gender difference is a socio-historical experience acting as a cause and reported as disrespect to humanity, neglect and abuse of elders. Further, studying the impact of aging on elders' abuse and neglect as social cause is the requirement for exploring new dimensions to rectify the prevailing situation in society (Arber \& Ginn, 1990; Brownell, 2016). The aging phenomena is responsible for physical causes while the differential in treating elders based on gender make them feeble and vulnerable to neglect. (Kim et al., 2005; Phelan \& Ayalon, 2020). On exploring the theoretical underpinning of aging, gender and abuse, the caregiver stress/situational theory propounded that the abuse occurs in an attempt 
to overcome the conflict and challenges of stress/burnout due to variation in caregiving by age (Phelan \& Ayalon, 2020). Further, the social exchange theory believes on transaction between the two persons is the basis of social and family relationship. When the imbalance between the members is felt (either to elder or caregiver) they undergo in conflict and abusive situation (Phelan \& Ayalon, 2020).

Further, at the age of 60 or above, female elder also faces poor physical health and get exposed to abuse more than male (Ayalon \& Huyck, 2001; Briones et al., 2002; Jeon et al., 2019; Spencer, 2016). A problem of falling, balancing and walking are most common in Dementia patient that need additional caring by caregiver but some time results in holding or locking the older adult patient in a room/house for managing regular household and workplace assignments for maintaining the balance between professional and caring responsibilities simultaneously (DeMarco, 2017; Flores et al., 2009), though it is not justified. For such act, the elders develop a prisoner like feeling and it is also considered as abusive behavior (Chwalinski, 2015). Thus, we can hypothesize:

H1: Elder's age has significant effect on their abuse.

\section{Gender and Elder Abuse}

Gender difference in prevailing society and natural aging are becoming the cause for elder abuse (Brownell, 2016). The conceptualization of aging along with gender provides the necessary information as a natural and social cause related to elder abuse (Kim et al., 2005; Phelan \& Ayalon, 2020). As per a study conducted by Lai (2007), Chinese women faces mental stress and lack of social support and they face physical and mental health issues more than the Chines men (W.L. Lai et al., 2014). On the basis of gender, women tend to face higher abuse or mistreatment or elder abuse in the form of intimate partner violence (IPV). Such mistreatment may be attributed to patriarchy and high masculine society (W. L. Lai et al., 2014). Bennett et al. (2000) analyzed that between the year 1997 to 1999, a 1085 women and 336 men called at elder people helpline. In the further studies "men were more likely to speak about mistreatment in public places" (Bowes et al., 2012, p. 265). On the other hand, women tend to keep the abuse secret due to traditional attitudes and values (Shim \& Nelson-Becker, 2009). However, women, with higher education are more likely to seek informal help then male (Bowes et al., 2012; Lee \& Eaton, 2009), but their attempt of reducing or avoiding abuse depends on the degree of dependence on their spouse, adult children and also on financial status (Shim \& Nelson-Becker, 2009; Guruge et al., 2010, p. 18). Such abuse and neglect are taken less seriously amongst elder female victims in comparison to their male counterpart (Burnes et al., 2019). Overcoming the abusive experiences starts from protective strategies such as avoidance, opposition, show of personal strengths, confirmation or justifying the abuse helps in coping up with tension and stress caused (Lafferty et al., 2012; Moos et al., 2006). Opposition helps to gain the control while personal strength of selfdetermination, resilience, and faith over caregiver, or himself, destiny or sometime on God facilitates in countering abuse (Aldwin, 1990; Janssen et al., 2011; Krause et al., 1991; Murrell et al., 1984). The confirmation strategy helps elders in assuring 
and justifying the abuse by reasons and the sources in front of another person like well-wisher, doctor, and police (Leisey et al., 2009; Payne, 2013; Schumacher et al., 1999). Thus, it was observed that elder abuse differs across gender (De Donder et al., 2011; Iborra, 2008) and there is a need to understand the impact of gender on elder abuse Therefore, we hypothesize:

$\mathrm{H} 2$ : Elder's gender has significant effect on their Abuse.

On believing the feminist arguments, the gender and power imbalance are related and prevalent in society (Yllo, 2005). Based on Domestic violence theory, the reports identified that females are prone to abuse rather than males (Naughton et al., 2010; WHO, 2018). The social learning theory points that every being change and adapt new behavior in society (Phelan \& Ayalon, 2020). Similarly, the respected and abusive behavior transmits and learned across the culture, society and generation in regular and normal manner with some gradual variations in demographic variable like age, gender etc. Hence, the prevalent theories, scholarly works and reports establish the fact that ageism and gender are significant dimension in elder abuse literature. Consequently, the present study was established on similar grounded theories that demography of elders has effect on their abusive experiences. The motivation behind the present study was to unveil the existence or prevalence of elder physical and psychological abuse due to the effects of aging and their gender.

The following hypotheses were established in prior to verify through statistical analysis based on attitude survey of elders. Thus, the hypothesis is as follows:

H3: Elder's gender and age interaction have significant effect on their abuse.

The methodology for addressing the aforesaid hypotheses is discussed as follows:

\section{Methodology}

The literature review led the foundations of varied research questions. In order to treasure the novel ripostes to the led research questions a proper methodology was commanded. From the above literature review, the presence of elder abuse in the society is established. The elder abuse tendency varies in demography as well. Due to aging, the elders get more susceptible to neglect and abuse due to physical health and elevated dependency over others. Mostly, the gender difference prevailing in society creates more complexities to vulnerable elders. Due to scant literature on demographic variables like gender and age as effecting variables in India on such a sensitive issue of elder abuse, published during recent years were Rashmi et al. (2020), Seth et al. (2019), Patel et al. (2018), Vardhan (2017), Nisha et al. (2016) discussed in depth as results obtained. Hence, the present study applied qualitative methods like observation and focus group interview to understand the deep roots of aging and gender effects on elder's neglect and abuse.

Based on exploration of abusive traces of elders due to demographic variables, the hypotheses were developed to verify through quantitative statistical method like factor analysis and variance analysis. The aforesaid hypotheses acted as beacon light for present research. Primarily, the instrument was developed to collect the sample data of elders. 


\section{Tool Development}

To riposte the research hypotheses, an appropriate survey tool was identified by using qualitative.

methods. Initially, qualitative methods were used to develop a survey instrument containing items related to psychological aspect, physical health and abuse tendency. During this stage, a rough questionnaire was drafted by investigators based on rigorous quantitative methods like review of related studies, observation of elders in natural setting, and focus group interview of agreed elders and medical practitioners (Kulshreshtha et al., 2019a). The group members were encouraged discussing the topic under study in-depth. The discussion is expected to be more fruitful in conducive environment. In this regard, the participants were contacted online as they were from different geographical locations. The moderator of the group who was one of the author understudy kept the discussion on the track for deeper understanding of the topic (Boddy, 2005; Muijeen et al., 2020). During focus group interview, the participants were informed about the purpose and assured for non-disclosure of identity to execute the discussion. The questions for dependent variable were adopted from previous study (Bajpai et al., 2020). Initially, there were 19 items but after an interview, the items reached to 31 in the questionnaire by extracting from the literature. In order to establish the content and face validity for scientific soundness of instruments the academicians were contacted and insights were gathered. The content and face validity were established by taking the reviews from academicians and medical professionals as well. Lastly, the developed survey instrument contains 29 items rated on five-point interval scale of agreement for each item.

The Table 1 exhibits the information about the finalized item of questionnaire. The developed questionnaire was used to collect the data from sampled participants.

\section{Sampling and Sample Profile}

The developed questionnaire was used to conduct the survey older adults folk of North India. The elders above 60 years of age were contacted on convenience to participate in the survey. The samples were drawn conveniently due to the unavailability of proper sampling frame for large population of Indian cities like Delhi, Mathura and Gwalior (Kulshreshtha et al., 2019b). The older adults were contacted at their homes, public places such as parks in morning hours, tea stalls, and even outside banks and hospitals. Two researcher having the prior experience of data collection were entrusted for collecting responses from the elderly people. Before starting with the survey questions, rapport building was done by asking some routine questions arising out of the then situation. In case the elderly is not willing or able to fill the data himself or herself, the questionnaire was narrated to him/her. Many a times, the local language i.e. Hindi was also used for improved understanding and comfort. The average interaction lasts for forty to fifty minutes. As the topic was sensitive, in the initial briefing by the moderator it was advised that while narrating the questions 
Table 1 Questionnaire Items

ABS1 Longevity of elder with the mental and/or physical inability invite caregiver to abuse him.

ABS2 The smaller family size causes relatively higher emotional abuse.

ABS3 I do not feel important among family members.

ABS4 Family stress or family crisis leads to emotional abuse.

ABS5 Habitual blaming or scapegoating hurts my emotions.

ABS6 I am made to feel guilty or distressed.

ABS7 My caregiver behaves menacingly toward me.

ABS8 I am emotionally blackmailed (threatened to withdraw access to grandchildren, family friends etc.).

ABS9 It seems like people do not give much time to me after their routine engagement.

ABS10 My caregiver declines the things I request.

ABS11 I am afraid of pursuing some leisure activities and interests.

ABS12 I feel powerless.

ABS13 I think to live alone.

ABS14 He/she tried to hit on me with the hand or object.

ABS15 I am restricted to a room.

ABS16 Sometimes I am afraid of being killed.

ABS17 I am not able to protect myself from someone.

ABS18 I feel weak from the inside for doing the activities of my daily routine.

ABS19 I am prone to physical injuries, such as a cut, burn, bruises or other marks on the body.

ABS20 Complaining to a police station or in some other agencies like NGO is not solution for abuse.

ABS21 My caregiver has already case registered against him/her in a police station.

ABS22 My caregiver is addicted to alcohol or any other substance.

ABS23 I frequently use spectacles with broken glass/Un Repaired hearing aid/ broken walking stick.

ABS24 I cry in secret.

ABS25 I am forced to do things I did not want to do.

ABS26 Anyone else makes decisions about my life-like how you should live or where you should live.

ABS27 I feel that nobody wants me around.

ABS28 I am not heard at times.

ABS29 I am not able to visit the tourist/religious destination of my choice.

the person responsible for data collection must remain neutral in terms of his voice or any other gesture or manner. At times, if the respondent became silent, he/she was reiterated about the fact that the data is for study purpose and highly confidential. The issue of socially desirability bias was addressed by giving more detailed information about the purpose of the research and generally collecting the data in private. Sometimes the respondents were asked the questions indirectly. Moreover, the respondents were assured about their anonymity. The initial sample contains 202 participants and second sample had 356 participants drawn by personally contacting more than 750 elders. The collected data was analyzed by using SPSS 23 and Amos statistical packages. 


\section{Results and Discussion}

For synchronization of research aim, there is a need of exploration and validation of measuring instrument and model underpinned with philosophy capable of implied practically. The synchronization was established in stages from exploration, validation and development of framework in sequence. Initially, the questionnaire containing 29 items or statement was used to approach 350 elders of aged 60 and above for collecting the responses. The 273 elders responded to the questionnaire and on verification, 202 were finally considered after eliminating unusable questionnaires for the analysis. The statistical tools like reliability test and factor analysis was applied to identify the factor and their measuring items affecting elder abuse. The output of reliability test through Cronbach alpha was found to be 0.891 larger than minimum expected value of 0.7 (Bajpai, 2011; Dubey et al., 2018; Hair et al., 2019). The higher value obtained in reliability test assure that the data is reliable to proceed for factor analysis.

The exploratory factors analysis (EFA) is the items reduction technique from the larger set of items statistically (Wiktorowicz, 2017). This technique is useful in exploring the factors and their measuring items for understudy variable. The Kaiser-Meyer-Olkin Measure of Sampling Adequacy and valued as 0.931 which is higher than 0.5 assuring that sample is adequate for exploratory factor analysis. The $\chi^{2}$ (Chi) square value in Bartlett's Test of Sphericity was obtained as 5810.492 at $d f=0.406$ is found significant at $p=0.01$ affirming that the correlation matrix is an identity matrix (Bajpai, 2017). Further, on analysis of Eigen values the three factors were valued more than 1 as 9.501, 6.577 and 3.262 enabling the sound extraction of factors. The cumulative variance acquired as $66.69 \%$ was sufficiently large; distributed under the three factors or components as 32.763, 22.680 and 11.249 (Hair et al., 2014). The extraction of items of three identified factors was performed by using Table 2 rotated component matrix. For obtaining sound discriminant validity, the threshold was considered to be 0.7 and larger (Hair et al., 2014). On observing the Table 2 the bolded items entered into the respective components. The items $A B S 3, A B S 9, A B S 18, A B S 28$ and $A B S 29$ were failed to enter in any of the components due to lower values than decided value of 0.7 (Table 2). The 11 measuring items $A B S 1, A B S 2, A B S 4, A B S 5, A B S 6, A B S 7, A B S 8, A B S 10, A B S 11, A B S 12$ and $A B S 13$ were extracted for component 1 nomenclature as Psychological abuse. The items $A B S 14, A B S 15, A B S 16, A B S 17, A B S 19, A B S 20, A B S 21$ and $A B S 22$ were extracted to measure component 2 named as Physical Abuse.

Finally, the extracted component 3 named as Elder Abuse i.e. measured by items $A B S 23, A B S 24, A B S 25, A B S 26$ and $A B S 27$. The eligible extracted factors were continued while items $A B S 3, A B S 9, A B S 18, A B S 28$ and $A B S 29$ were dropped from the questionnaire. The new formatted questionnaire containing 24 statistically extracted was utilized to conduct the second survey for validating the measuring instrument through confirmatory factor analysis. Further, the confirmatory factor analysis was used to second-tier sampled data of 356 participants for checking the validity of scale or instrument. The CFA framework was designed for confirming the variables psychological abuse (PSYCA) with 11 measuring items, physical abuse (PHYA) with 8 measuring items and elder abuse (ABU) with 5 measuring items. 
Table 2 Rotated Component Matrix $^{\mathrm{a}}$

\begin{tabular}{|c|c|c|c|c|c|c|c|}
\hline \multirow[t]{2}{*}{ Items } & \multicolumn{3}{|c|}{ Component } & \multirow[t]{2}{*}{ Items } & \multicolumn{3}{|c|}{ Component } \\
\hline & 1 & 2 & 3 & & 1 & 2 & 3 \\
\hline BS1 & 0.976 & 0.019 & 0.031 & ABS16 & 0.069 & 0.906 & 0.014 \\
\hline BS2 & 0.908 & 0.027 & 0.051 & ABS17 & -0.011 & 0.897 & 0.026 \\
\hline BS3 & 0.017 & 0.068 & -0.046 & ABS18 & 0.122 & 0.068 & -0.018 \\
\hline BS4 & 0.918 & 0.083 & 0.035 & ABS19 & 0.104 & 0.918 & 0.027 \\
\hline BS5 & 0.902 & 0.056 & 0.032 & ABS20 & .064 & 0.904 & -0.014 \\
\hline BS6 & 0.891 & 0.034 & 0.044 & S21 & -0.011 & 0.920 & -0.064 \\
\hline BS7 & 0.899 & 0.017 & 0.058 & ABS22 & 0.062 & 0.907 & 0.037 \\
\hline BS8 & 0.899 & 0.065 & 0.021 & $\mathrm{ABS} 23$ & -0.045 & -0.108 & 0.820 \\
\hline לדים & 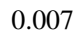 & -0.199 & -0.059 & 4 & 54 & -0.002 & 0.779 \\
\hline BS10 & 0.910 & 0.002 & 0.067 & ABS25 & 0.042 & 0.062 & 0.802 \\
\hline ABS11 & 0.897 & 0.103 & 0.035 & ABS26 & -0.006 & 0.045 & 0.810 \\
\hline ABS12 & 0.896 & 0.037 & -0.006 & ABS27 & 0.053 & 0.057 & 0.816 \\
\hline $\mathrm{BS} 13$ & 0.927 & 0.008 & -0.002 & ABS28 & 0.183 & -0.011 & -0.095 \\
\hline ABS14 & 0.067 & 0.972 & 0.014 & ABS29 & 0.075 & -0.064 & -0.046 \\
\hline BS15 & 0.066 & 0.903 & -0.037 & & & & \\
\hline
\end{tabular}

Extraction Method: Principal Component Analysis. Rotation Method: Varimax with Kaiser Normalization

${ }^{a}$ Rotation converged in 4 iterations

Confirmatory factor analysis is significant thespian in the field of social science, humanities, education and management studies (Crede \& Harms, 2019; Marsh et al., 2020). This technique is determined in judging the fitness of measurement model with underlying default model. It gives substantial analysis and results by judging the validity against several indices. Some prominent model fit indices like Goodness of fit Index (GFI), Adjusted Goodness of Fit Index (AGFI), Comparative Fit Index (CFI), Root Mean Square Error of Approximation (RMSEA), Tucker Lewis Index (TLI) and Parsimonious Comparative Fit Index (PCFI) values must range between 0 to 1 , while RMSEA value should fall below 0.08 were used to judge the validity of model (Schumacker \& Lomax, 2004). In present study, the second survey tabulated data was used for application CFA by using AMOS v 23.0. The analysis outcomes of confirmatory factor analysis results shown the $\chi 2$ test resulted as 262.877 at $\mathrm{p}=0.261(\mathrm{p}>0.05)$ and CMIN/ Df was 1.056 (ranged between 1-5) at $\mathrm{df}=249$ establishing badness of fit index (Bajpai, 2017; Dubey et al., 2019). The CFA results circumscribed the imperative indices $G F I=0.944, A G F I=0.932, C F I=0.999$, RMSEA $=0.013$, $\mathrm{P}$ close $=1.000, \mathrm{TLI}=0.998$ and PCFI $=0.901$ were in its acceptable range (Bajpai, 2017).

On fulfilling the necessary condition, it is viable to realize sufficient condition also for verifying scientific model. To consummate, the Table 3 validity test screens the standardized regression weights, AVE and CR values attained for the presented factors of CFA model. The average variance extracted (AVE) for psychological abuse, physical abuse and elder abuse as $0.811,0.815$ and 0.635 . All these values are above the threshold level of 0.5 affirming the validation of scale. The composite 
Table 3 Validity Test

\begin{tabular}{|c|c|c|c|c|}
\hline Counts & Antecedents & $\begin{array}{l}\text { Standardized } \\
\text { Regression Weights }\end{array}$ & AVE & $\mathrm{CR}$ \\
\hline 1 & PSYCA1 & 0.984 & 0.811 & 0.98 \\
\hline 2 & PSYCA2 & 0.900 & & \\
\hline 3 & PSYCA3 & 0.906 & & \\
\hline 4 & PSYCA4 & 0.886 & & \\
\hline 5 & PSYCA5 & 0.893 & & \\
\hline 6 & PSYCA6 & 0.886 & & \\
\hline 7 & PSYCA7 & 0.880 & & \\
\hline 8 & PSYCA8 & 0.895 & & \\
\hline 9 & PSYCA9 & 0.894 & & \\
\hline 10 & PSYCA10 & 0.882 & & \\
\hline 11 & PSYCA11 & 0.899 & & \\
\hline 1 & PHYA1 & 0.981 & 0.815 & 0.97 \\
\hline 2 & PHYA2 & 0.888 & & \\
\hline 3 & PHYA3 & 0.877 & & \\
\hline 4 & PHYA4 & 0.883 & & \\
\hline 5 & PHYA5 & 0.902 & & \\
\hline 6 & PHYA6 & 0.895 & & \\
\hline 7 & PHYA7 & 0.902 & & \\
\hline 8 & PHYA8 & 0.894 & & \\
\hline 1 & ABU1 & 0.924 & 0.635 & 0.89 \\
\hline 2 & ABU2 & 0.789 & & \\
\hline 3 & ABU3 & 0.710 & & \\
\hline 4 & $\mathrm{ABU} 4$ & 0.735 & & \\
\hline 5 & ABU5 & 0.808 & & \\
\hline
\end{tabular}

reliability (CR) of each factor is also found larger than 0.7 in Table 3. Together AVE and $\mathrm{CR}$ had fulfilled the sufficient condition of validity establishment of measurement scale (Bajpai, 2017).

The data was further analyzed to evident the effect of age and gender on elder abuse. The Table 4 descriptive statistics exhibits the gender and age group distribution of collected sample. There were 168 females and 188 males distributed under the aforesaid age groups exhibited in Table 4 . The Table 4 also exhibit that the abuse mean score of males were higher than of females with their respective standard deviation. The assumptions of gender and age effect was traced but for rational output to establish the generalized thought the two-way ANOVA was implied and exhibited in Table 5 .

The Table 5 exhibit the effect of age, gender and their composite effect on elder abuse. Primarily, the coefficient of determination i.e. $R$ Squared $=0.836$ is sufficiently large in predicting the understudy independent variable of elder abuse affect by $83.6 \%$ due to age, gender and composite effect (Bajpai, 2017). This leads to proceed for hypotheses testing. The F-value $=577.812$ was found significant as 
Table 4 Descriptive Statistics

\begin{tabular}{lllll}
\hline Dependent & Variable: Abuse & & & \\
\hline Gender & Age-group & Mean & Std. Deviation & $\mathrm{N}$ \\
\hline Female & $60-70$ & 9.852 & 1.441 & 155 \\
& $70-80$ & 11.000 & 1.000 & 13 \\
& Total & 9.940 & 1.442 & 168 \\
Male & $60-70$ & 18.020 & 2.861 & 99 \\
& $70-80$ & 20.469 & 3.070 & 64 \\
& $80 \&$ above & 23.240 & 0.436 & 25 \\
& Total & 19.548 & 3.292 & 188 \\
Total & $60-70$ & 13.035 & 4.513 & 254 \\
& $70-80$ & 18.870 & 4.552 & 77 \\
& $80 \&$ above & 23.240 & 0.436 & 25 \\
& Total & 15.014 & 5.455 & 356 \\
\hline
\end{tabular}

$p=0.000$ confirming the acceptance of alternative hypothesis $\mathrm{H} 2$ that elders gender had significant effect on their abuse. The value of F-value $=48.515$ having mean square of 239.401 was found significant as $p$ value $=0.000$ leading to accept alternative hypothesis value $\mathrm{H} 1$ that the age of elders had significant effect on their abuse. Lastly, the value of $\mathrm{F}$-value $=3.140$ was identified significant as the $p$ value $=0.077$ having mean square value 15.494 assuring the acceptance of hypothesis $\mathrm{H} 3$ at $10 \%$ level of significance that gender type and age achieved by elders compositely effect the abusive behavior towards them. The acceptance of three alternative hypotheses with sufficient evidences concludes the present research that elder being male/ female or aging and both have due effect on their abuse from physical to psychological (mental) level.

The ageism is methodical and stereotypical style to older people observed in others behavior and attitude in day-to-day life. The present study identified similar

Table 5 Tests of Between-Subjects Effects

\begin{tabular}{|c|c|c|c|c|c|c|}
\hline \multicolumn{7}{|c|}{ Dependent Variable: Abuse } \\
\hline Source & $\begin{array}{l}\text { Type III Sum } \\
\text { of Squares }\end{array}$ & $\mathrm{df}$ & Mean Square & $\mathrm{F}$ & Sig & $\begin{array}{l}\text { Partial Eta } \\
\text { Squared }\end{array}$ \\
\hline Corrected Model & $8830.886^{\mathrm{a}}$ & 4 & 2207.721 & 447.396 & 0.000 & 0.836 \\
\hline Intercept & $35,046.542$ & 1 & $35,046.542$ & 7102.207 & 0.000 & 0.953 \\
\hline Gender & 2851.272 & 1 & 2851.272 & 577.812 & 0.000 & 0.622 \\
\hline Age & 478.803 & 2 & 239.401 & 48.515 & 0.000 & 0.217 \\
\hline Gender * Age & 15.494 & 1 & 15.494 & 3.140 & 0.077 & 0.009 \\
\hline Error & 1732.044 & 351 & 4.935 & & & \\
\hline Total & $90,813.000$ & 356 & & & & \\
\hline Corrected Total & $10,562.930$ & 355 & & & & \\
\hline
\end{tabular}

${ }^{\mathrm{a}} \mathrm{R}$ Squared $=0.836($ Adjusted R Squared $=0.834)$ 
findings like Nelson, (2005) as elders being second-class citizen while Phelan and Ayalon (2020) concluded that elders have elevated risk for abuse perpetration due to aging. The present study identified.

that gender has prominent effect on elders as identified by Weeks et al. (2018) through online survey on capacity to respond against abuse due to the exclusive needs of older male and female. The ageism and gender type also affect the elders miserably by abuse. Though, elders are affected by aging naturally while the gender differences social cause effects venomously when combined with aging creating worries, tension, neglect and abuse (Jeon et al., 2019; Kumar \& Bhakat, 2020; Nelson, 2005; Phelan \& Ayalon, 2020). The present study strained a social inkling of elders for improvement in environments of elders as every group or family have elders who flourishes the members by experience and care. The study is a classic example that the issues related to elder abuse and neglect are growing than ever. Different nations as welfare states and custodian of older adults' asset. The level of care and welfare of older adults taken by the particular society is an indicator of civilization.

There are evidences that older people like to settle finally in the set up conducive for older adults. However, it has been observed that the older adults may be abused in domestic as well as institutional setting (Lai et al., 2014). In most of the cases it is exercised by the person on whom he or she relies for physical and psychological support. Some studies suggest that the abuse towards women is high (Lai, 2004; Lai \& Chau, 2007). However, in most of the cases it is in the cases of intimate partner abuse (Lai et al., 2014). Moreover, the age of the person is also one of the responsible factors for increased chances of elder abuse.

The fact that women have longer life span than men put her at the higher risk of elder abuse. Especially when the women are widow, less educated and have financial dependency. On the other side, men are also having higher chances of elder abuse as they avoid seeking help of local community unlike women. The abuse towards men may be attributed to several gender specific reasons (ILO, 2009). While men are more aware about where to approach in the case of elder abuse, women tends to seek help from the neighbors unlike men. As per the United Nations, the states must ensure that the people can grow old with security and dignity having no discrimination of any form. This can be achieved by strengthening primary health care and social service sector for identifying and resolving EA.

\section{Conclusion}

Elders have social obligations of preaching and nourishing forthcoming generation with their thought, learning and experiences (Arroyo et al., 2021). The present study reported the novel ways of exploring elder abuse through demographic profiles. The present study identified the contribution of gender differential in neglect and abuse of elders along with natural aging phenomena. As a logical positivist, these issues can be resolved by simplistic logical reasoning, as behavior of any child and elder is similar due to considered factors. Further, as 
post-modernist, the youth are required to refrain themselves from these ill practices of neglect and abused of elders by realizing the basic humanitarian value system. The present generation is required to notice the changes in the situations of elders for better care, as once everyone has to undergo to complete the journey of life with pleasure or distress.

The current findings are in line with (Bennett et al., 2000) that the age is one of the crucial factor attracting the mistreatment of older adults. The research conducted by Bennett et al. (2000) depicted that the occurrence of elder abuse increases with the age and showed a decline after 85 years of age. However, the results are contrary to the findings suggested by Asti and Erdem (2006) that gender and economic status does not affect the degree of elder abuse. Moreover, the current study provides a fully developed scale useful for identifying the prevalence of elder abuse has endorsement by Pelotti et al. (2013) stating that early detection of EA helps reducing the adverse impacts of it.

\section{Implications}

Pertaining to this social tearing effect on elders, there may be the chances of longitudinal study required for illustration on causalities of relatedness among vulnerable factors (social, psychological and demographic) and abuse. The presented particular study relating the issues of gender difference, natural ageism and composite effect on elders is a novel social research for future insights. Therefore, a vital opportunity of the interventional studies on the objectives of present study would better generalize the results. The present study is concerned about physical and psychological well-being of elders. The government, social organization and non-government organization (NGO) can identify the traces of physical abuse, which is more visible than psychological abuse of elders, and build an action plan for their protection. Individually, the caregiver avoids the habit of blaming and scapegoating elders, as they are vulnerable due to aging and weakness. There exists a vital necessity of creating awareness, interest, attitude and action oriented policy measures at regional and national level to shield the vulnerable elders in society. Elder abuse is a psychological morbidity to the elder and perpetrators; needs a remedial measure for wellness of both and society. In this regard, the policymakers may explore the possibilities of deputing lawyers, bank professionals, teachers, general practitioners, retired police officers to be appointed as a non- judicial ombudsman. Such persons may act as a nodal person to record and report such cases. It is worth mentioning that ideally they should act as a mediator to resolve the dispute. The reporting can be made to the district level centralize repository under the administrative control of district administration and agencies. The help of University as a nodal center can also be taken in counselling and documenting initial observations, facts, circumstances and assessment so that the same can be used by further government agencies such as elder welfare board, police, local administration and court. Further, based on the facts that age and gender has a direct bearing on elder abuse, the regular sensitization workshop must be conducted to identify the elder abuse especially in the schools 
and colleges by NGOs, University, Colleges and other related and most importantly interested organization. The fact that the police, administration and courts are already burdened enough to deal with the existing cases cannot be ignored. The setting up of aforesaid quasi-judicial or local civil body arrangement will be a turning point for elders. Such becomes significant as addressing the elder abuse while respecting relationship and encouraging the abuser to change is one of the major challenge (Taylor \& Donnelly, 2006). The mobile app for registering a complaint or a message facility to send the information about the prevalence of elder abuse must also be developed. In the case of change in will document or transfer of property, solicitor must endorse that 'no incidence of elder abuse is apparent'. Bank officials must also ensure by making a phone call or otherwise if there is a withdrawal or transfer of the amount than usual. The elders who are receiving pension might be asked to submit declaration of No-Elder Abuse occurrence along. It is important to note that all such activities are effective when there is an active supervising body/organization available in this regard. It was rightly observed that "Preventing and responding to abuse requires awareness of abuse" (Begley et al., 2012, p. 57). In addition, the aforesaid suggestions are in line with the work of Bennett et al. (2000), where the title of the paper conveying the clear message that "Listening is not enough" (p. 6). Thus, the topic how to identify and report elder abuse must be the part of course curriculum at school and again at college level for making the citizen especially youngster more responsible for reporting and indemnifying such case. Moreover, this will also desist the caretaker (in most of the cases relatively younger person) to be a preparatory for elder abuse. Generally, in the present modern time all especially older adults avoid sharing about the mistreatment against them. In most of the cases they avoid contacting agencies for eliminating or reducing the prevalence of elder abuse. In such cases the aforesaid suggestions will be beneficial in reducing the occurrence of elder abuse. In addition, the government may also strive to provide the security measures to elder people in the form of accessible health facilities, pension and setting up social network for easy reporting of cases for early remedial actions.

\section{Limitation and Scope of Future Research}

The present study had certain limitations like the characteristics; nature and scope of caregivers contributing to elders were not considered. The recall bias was also a major issue pertaining in present study, as participants were vulnerable elders. The present study was conducted under the periphery of physical and psychological abuse of elders. Some other recent social factors like dependence, vulnerability, changes in cultural and value system over time and generation would have been considered. Further, not all elders on age and gender were considered under present study but there are variety of social causes like education level and occupation would be considerate for further research. The research is limited up to a specific geographical location like India does not result in holistic insinuation of demographic effects on elders. The limitations can become the source for novel implications for future 
researchers and social scientists. Further, the moderating effect of certain factors such as type of family, society norms, government interventions etc. can be examined. Moreover, the role of gender of caregiver may also be examined in future studies. At last, it will be interesting to examine the mediating role of intelligence quotient (I.Q.) of caregivers and older adults in the context of elder abuse.

Acknowledgements This study was funded by Indian Council of Social Science Research, (ICSSR), New Delhi, India. No. 02/240/ 2016-17/RP, 2017-2019.

\section{Declarations}

Conflicts of Interest The authors declare that they have no conflicts of interest.

Informed Consent Informed consent was obtained from all participants included in the study.

Ethical Approval This article does not contain any studies with human participants or animals performed by any of the authors.

\section{References}

Acierno, R., Hernandez, M. A., Amstadter, A. B., Resnick, H. S., Steve, K., Muzzy, W., \& Kilpatrick, D. G. (2010). Prevalence and correlates of emotional, physical, sexual, and financial abuse and potential neglect in the United States: The national elder mistreatment study. American Journal of Public Health, 100(2), 292-297. https://doi.org/10.2105/AJPH.2009.163089

Aldwin, C. M. (1990). The Elders Life Stress Inventory: Egocentric and no egocentric stress. In M. A. P. Stephens, J. H. Crowther, S. E. Hobfoll, \& D. L. Tennenbaum (Eds.), Series in applied psychology. Stress and coping in later-life families (p. 49-69). Hemisphere Publishing Corp. https://doi.org/10. 4324/9781315803074

Anderson, J. (2017). "Family conflicts over elderly parents", available at: https:/www.aplaceformom.com/ blog/when-siblings-clash-about-parents-care/ (accessed 09 November 2017).

Arber, S., \& Ginn, J. (1990). The meaning of informal care: Gender and the contribution of elderly people. Ageing \& Society, 10(4), 429-454. https://doi.org/10.1017/S0144686X00007406

Arroyo, I., Montesino, N., Johansson, E. \& Yahia, M. W. (2021). Social integration through social connection in everyday life. Residents' experiences during the COVID-19 pandemic in SällBo collaborative housing, Sweden. Archnet-IJAR, 15(1), 79-97. https://doi.org/10.1108/ARCH-10-2020-0236

Asti, N., \& Erdem, N. (2006). A pilot study on the abuse of elderly people with dementia in Turkey. The Journal of Adult Protection, 8(4), 13-19. https://doi.org/10.1108/14668203200600024

Astin, M. C., Lawrence, K. J., \& Foy, D. W. (1993). Posttraumatic stress disorder among battered women: Risk and resiliency factors. Violence and Victims, 8(1), 17-28. https://doi.org/10.1891/vv.8.1

Ayalon, L., \& Huyck, M. H. (2001). Latino caregivers with Alzheimer's disease. Clinical Gerontologist, 24(3/4), 93-106. https://doi.org/10.1300/J018v24n03_08

Bajpai, N. (2011). Business Research Methods. Pearson Education India.

Bajpai, N. (2017). Business Research Methods, 2nd ed., Pearson India Education Services Pvt. Ltd.

Bajpai, N., Kulshreshtha, K., Dubey, P., \& Sharma, G. (2020). Getting the cues of elder abuse: An identification through dependency and modernization. The Journal of Adult Protection, 22(3), 119-139. https://doi.org/10.1108/JAP-10-2019-0035

Barrett, K. A., O’Day, B., Roche, A., \& Carlson, B. L. (2009). Intimate partner violence, health status, and health care access among women with disabilities. Women's Health Issues, 19(2), 94-100. https://doi.org/10.1016/j.whi.2008.10.005

Beach, S. R., Schulz, R., Williamson, G. M., Miller, L. S., Weiner, M. F., \& Lance, C. E. (2005). Risk factors for potentially harmful informal caregiver behavior. Journal of the American Geriatrics Society, 53(2), 255-261. https://doi.org/10.1111/j.1532-5415.2005.53111.x 
Begley, E., O’Brien, M., Carter Anand, J., Killick, C., \& Taylor, B. (2012). Older people's views of support services in response to elder abuse in communities across Ireland. Quality in Ageing and Older Adults, 13(1), 48-59. https://doi.org/10.1108/14717791211213616

Bennet, G., \& Kingston, P. (1993). Elder abuse: Concepts, theories and interventions. Chapman and Hall.

Bennett, G., Jenkins, G., \& Asif, Z. (2000). Listening is not enough: An analysis of calls to the Elder Abuse Response. The Journal of Adult Protection, 2(1), 6-20. https://doi.org/10.1108/14668203200000003

Boddy, C. (2005). A rose by any other name may smell as sweet but "group discussion" is not another name for a "focus group" nor should it be. Qualitative Market Research, 8(3), 248-255. https://doi.org/10. $1108 / 13522750510603325$

Bowers, B. C., Hawes, C., \& Burger,. (2003). "Focus group interviews with family members of nursing home residents and individual interview with residents about the complaint process", School of Nursing, University of Wisconsin at Madison and the School of Rural Public Health. Texas A\&M University System Health Science Center.

Bowes, A., Avan, G., \& Macintosh, S. B. (2012). Cultural diversity and the mistreatment of older people in Black and minority ethnic communities: Some implications for service provision. Journal of Elder Abuse \& Neglect, 24(3), 251-274. https://doi.org/10.1080/08946566.2011.653319

Bradbury-Jones, C., \& Isham, L. (2020). The pandemic paradox: The consequences of COVID-19 on domestic violence. 2047-2049. Available at: https://onlinelibrary.wiley.com/doi/epdf/https://doi. org/10.1111/jocn.15296 (Accessed on 10 June 2021).

Briones, D. F., Ramirez, A. L., Guerrero, M., \& Ledger, E. (2002). Determining cultural and psychosocial factors in Alzheimer disease among Hispanic populations. Alzheimer Disease and Associated Disorders, 16(Supplement 2), S86-S88.

Brownell, P. (2016). A reflection on gender issues in elder abuse research: Brazil and Portugal. Ciência \& Saúde Coletiva, 21, 3323-3330. https://doi.org/10.1590/1413-812320152111.23142016

Broyles, K. (2000). The silenced voice speaks out: A study of abuse and neglect of nursing home residents. Atlanta, GA: A report from the Atlanta Long Term Care Ombudsman Program and Atlanta Legal Aid Society to the National Citizens Coalition for Nursing Home Reform.

Bucher, J., Loscalzo, M., Zabora, J., Houts, P. S., Hooker, C., \& BrintzenhofeSzoc, K. (2001). Problemsolving cancer care education for patients and caregivers. Cancer Practice, 9(2), 66-70. https://doi. org/10.1046/j.1523-5394.2001.009002066.x

Burgess, A. W., Dowdell, E., \& Prentky, R. (2000). Sexual abuse of nursing home residents. Journal of Psychosocial Nursing, 38(6), 10-18. https://doi.org/10.3928/0279-3695-20000601-09

Burnes, D., Lachs, M. S., Burnette, D., \& Pillemer, K. (2019). Varying appraisals of elder mistreatment among victims: Findings from a population-based study. The Journals of Gerontology: Series B, 74(5), 881-890. https://doi.org/10.1093/geronb/gbx005

Bursack, C. B. (2012). “Top 3 excuses from siblings who don't help with caregiving”, available at: https://web2.uconn.edu/hrnew/docs/getting_siblings_involved.pdf (accessed 02 December 2017).

Carl, C. (2015). "Dealing with unsupportive family", community wisdom, available at: https://thecaregiv erspace.org/dealing-with-unsupportive-family/ (accessed 14 November 2017).

Census of India. (2011). Provisional Census, available at: https://www.censusindia.gov.in

Centers for Disease Control and Prevention. (2021). Alzheimer's disease and healthy aging: "loneliness and social isolation linked to serious health conditions", Available at: https://www.cdc.gov/aging/publications/features/ lonely-older-adults.html (Accessed on 10 June 2021).

Chang, E. S., \& Levy, B. R. (2021). High prevalence of elder abuse during the COVID-19 pandemic: risk and resilience factors. The American Journal of Geriatric Psychiatry. S1064-7481(21) 00018-X. https://doi.org/10.1016/j.jagp.2021.01.007

Chang, E. S., \& Levy, B. R. (2021b). High prevalence of elder abuse during the COVID-19 pandemic: Risk and resilience factors. The American Journal of Geriatric Psychiatry. https://doi.org/10. 1016/j.jagp.2021.01.007

Chwalinski, P. (2015). "A nursing home nightmare", available at: https://thecaregiverspace.org/a-nursinghome-nightmare/ (accessed 16 November 2017).

Comijs, H. C., Pot, A. M., Smit, J. H., Bouter, L. M., \& Jonker, C. (1998). Elder abuse in the community: Prevalence and consequences. Journal of American Geriatr Society, 46(7), 885-888. https://doi. org/10.1111/j.1532-5415.1998.tb02724.x

Craven, R. F., \& Hirnle, C. J. (2003). Fundamentals of nursing: Human health and function (4th ed.). Lippincott Williams and Wilkins. 
Crede, M., \& Harms, P. (2019). Questionable research practices when using confirmatory factor analysis. Journal of Managerial Psychology, 34(1), 18-30. https://doi.org/10.1108/JMP-06-2018-0272

Cunningham, A. (1998). "Theory-Derived Explanations of Male Violence against Female Partners: Literature Update and Related Implications for Treatment and Evaluations", London, ON: London Court Clinic, available at: http://www.lfcc.on.ca/maleviolence.html (Accessed on 06 November 2017).

De Donder, L., Lang, G., Luoma, M., Penhale, B., Ferreira Alves, J., Tamutiene, I., Santos, A. J., Koivusilta, M., Enzenhofer, E., Perttu, S., Savola, T., \& Verté, D. (2011). Perpetrators of abuse against older women: A multi-national study in Europe. The Journal of Adult Protection, 13(6), 302-314. https:// doi.org/10.1108/14668201111194212

DeMarco, B. (2017). "6 Reasons Why You Might Have to Put Someone with Dementia in a Memory Care Facility or Nursing Home", available at: http://www.alzheimersreadingroom.com/2016/12/ alzheimers-dementia-care-6-reasonswhy-you-might-have-to-put-someone-with-dementia-in-memory-care.html (accessed 16 November 2017).

Donelan, K., Hill, C. A., Hoffman, C., Scoles, K., Feldman, P. H., Levine, C., \& Gould, D. (2002). Challenged to care: Informal caregivers in a changing health system. Health Affairs, 21(4), 222-231. https://doi.org/10.1377/hlthaff.21.4.222

Dryer, D. E. (2007). "The Phenomenon of Powerlessness in the Elderly", available at: https://www.svsu. edu/media/writingcenter/Dryer_article.pdf (accessed 13 November 2017).

Dubey, P., Bajpai, N., \& Guha, S. (2018). Classifying customer "wow", 'aha', and "cool” affect through arousal: A study on mobile users. International Journal of Electronic Marketing and Retailing, 9(1), 37-58. https://doi.org/10.1504/IJEMR.2018.088588

Dubey, P., Bajpai, N., Guha, S., \& Kulshreshtha, K. (2019). Entrepreneurial marketing: An analytical viewpoint on perceived quality and customer delight. Journal of Research in Marketing and Entrepreneurship, 22(1), 1-19. https://doi.org/10.1108/JRME-09-2016-0033

Flores, Y. G., Hinton, L., Barker, J. C., Franz, C. E., \& Velasquez, A. (2009). Beyond Familism: Ethics of Care of Latina Caregivers of Elderly Parents with Dementia. Health Care for Women International, 30(12), 1055-1072. https://doi.org/10.1080/07399330903141252

Follingstad, D., \& DeHart, D. (2000). Defining psychological abuse of husbands toward wives: Contexts, behaviors, and typologies. Journal of Interpersonal Violence, 15(9), 891-920. https://doi.org/10. 1177/088626000015009001

Friedman, B., Santos, E. J., Liebel, D. V., Russ, A. J., \& Conwell, Y. (2015). Longitudinal prevalence and correlates of elder mistreatment among older adults receiving home visiting nursing. Journal of Elder Abuse and Neglect., 27(1), 34-64. https://doi.org/10.1080/08946566.2014.946193

Given, B., Given, C. W., Stommel, M., \& Lin, C. S. (1994). Predictors of use of secondary carers used by the elderly following hospital discharge. Journal of Aging Health, 6(3), 353-376. https://doi.org/ $10.1177 / 089826439400600305$

Gonçalves, L. H. T., Costa, M. A. M., Martins, M. M., Nassar, S. M., \& Zunino, R. (2011). The family dynamics of elder elderly in the context of Porto. Portugal. Revista Latinoamericanade Enfermagem, 19(3), 458-466. https://doi.org/10.1590/S0104-11692011000300003

Govil, P., \& Gupta, S. (2016). Domestic Violence against Elderly People: A Case Study of India. Advances in Aging Research, 5(5), 110-121. https://doi.org/10.4236/aar.2016.55011

Graham-Harrison, E., Giuffrida, A., Smith. H. \& Ford, L. (2020). Lockdowns around the world bring rise in domestic violence. The Guardian March 28, 2020. Retrieved January 12, 2021, from https:// www.theguardian.com/society/2020/mar/28/lockdowns-world-risedomestic-violence

Guruge, S., Kanthasamy, P., Kokarasa, J., Wan, T. Y. W., Chinichian, M., Shirpak, K. R., Paterson, P. \& Sathananthan, S. (2010). Older women speak about abuse \& neglect in the post-migration context. Women's Health and Urban Life, 9 (2), 15-41. http://hdl.handle.net/1807/25498

Hair, F. H., William, C. B., Barry, J. B. \& Anderson, R. E. (2014). Multivariate Data Analysis, Pearson India.

Hair, J. F., Black, W. C., Babin, B. J., \& Anderson, R. E. (2019). Multivariate data analysis (8th ed.). Cengage Learning.

Hamarman, S., \& Bernet, W. (2000). Evaluating and reporting emotional abuse in children: Parentbased, action-based focus aids in clinical decision-making. Journal of the American Academy of Child and Adolescent Psychiatry, 39(7), 928-930. https://doi.org/10.1097/00004583-200007000-00023

Hammer, R. (2001). Antifeminism and Family Terrorism: A Critical Feminist Perspective. Rowan \& Little field Publishers. 
HelpAge India. (2017). "Elder Abuse", Available at https://www.helpageindia.org/elderabuse/ (Accessed on 21 June 2021).

HelpAge India. (2014). "State of elderly in India", New Delhi, available at: https://www.helpageindia.org/ images/pdf/state-elderly-india-2014.pdf (Accessed 18 November 2017).

Hill, M. (2017)."Is Your Loved One a Victim of Elder Abuse and Neglect? Know the Signs!", available at: https://www.eadiehill.com/nursing-home-articles/loved-one-victimelder-abuse-neglect-knowsigns/ (accessed 11 November 2017).

Homer, A. C., \& Gilleard, C. (1990). Abuse of elderly people by their carers. Journal of British Medicine, 30(1), 1359-1362. https://doi.org/10.1136/bmj.301.6765.1359

Horgas, A. \& Abowd, G. (2004). The Impact of Technology on Living Environments for Older Adults. In: National Research Council (US) Steering Committee for the Workshop on Technology for Adaptive Aging, Technology for Adaptive Aging, Washington (DC), National Academies Press (US), Available from: https://www.ncbi.nlm.nih.gov/books/NBK97336/

Iborra, M.I. (2008). “Older Adults' Mistreatment Within Spanish Families”, Queen Sofı'a Center, Foundation of the Valencia Community for the Study of Violence, Valencia (in Spanish).

ILO. (2009). "Ageing societies: The benefits, and the costs, of living longer", Available at: https://www. ilo.org/global/WCM_041965/lang--en/index.htm (Accessed on 12 June 2021).

Jamshidi, R., Oppenheimer, A. J., Lee, D. S., Lepar, F. H., \& Espenshade, T. J. (1992). Aging in America: Limits to life span and elderly care options. Population Research and Policy Review, 11(2), 169190. https://doi.org/10.1007/BF00125537

Janssen, B. M., Van Regenmortel, T., \& Abma, T. A. (2011). Identifying sources of strength: Resilience from the perspective of older people receiving long-term community care. European Journal of Ageing, 8(3), 145-156. https://doi.org/10.1007/s10433-011-0190-8

Jeon, G. S., Cho, S. I., Choi, K., \& Jang, K. S. (2019). Gender differences in the prevalence and correlates of elder abuse in a community-dwelling older population in Korea. International Journal of Environmental Research and Public Health, 16(1), 1-13. https://doi.org/10.3390/ijerph16010100

Kim, O. S., Yang, K. M., \& Kim, K. H. (2005). Dependency, abuse, and depression by gender in widowed elderly. Journal of Korean Academy of Nursing, 35(2), 336-343. https://doi.org/10.4040/ jkan.2005.35.2.336

Kosberg, J. I. (1990). Assistance to victims of crime and abuse. Handbook of gerontological services, $450-473$.

Kosberg, J. I., \& Garcia, J. L. (1995). Confronting maltreatment of elders by their family. Strengthening aging families, 63-79, Thousand Oaks, CA: Pinc Forge Press.

Kosberg, J. I. (1988). Preventing elder abuse: Identification of high-risk factors prior to placement. The Geronlologist, 28(1), 43-50. https://doi.org/10.1093/geront/28.1.43

Krause, N., Gina, J., \& Liang, J. (1991). Financial strain and psychological well-being among the American and Japanese elderly. Psychology \& Aging, 6(2), 170-181. https://doi.org/10.1037/08827974.6.2.170

Kubsch, S., \& Wichowski, C. H. (1997). Restoring power through nursing intervention. Nursing Diagnosis, 8(1), 7-15. https://doi.org/10.1111/j.1744-618X.1997.tb00127.x

Kulshreshtha, K., Bajpai, N., Tripathi, V. \& Sharma, G. (2019a). Cause-related marketing: an exploration of new avenues through conjoint analysis. Benchmarking: An International Journal, 26(6). 2017-2050. https://doi.org/10.1108/BIJ-05-2018-0131.

Kulshreshtha, K., Bajpai, N., Tripathi, V., \& Sharma, G. (2019b). Consumer preference for ecofriendly appliances in trade-off: A conjoint analysis approach. International Journal of Product Development, 23(2-3), 212-243. https://doi.org/10.1504/IJPD.2019.099237

Kumar, Y., \& Bhakat, P. (2020). Aging and social networks: A perspective on gender disparity in India. Journal of Women \& Aging, 1-19. https://doi.org/10.1080/08952841.2020.1718581

Lachs, M. S., Williams, C. S., \& O’brien, S., Pillemer, K. A., \& Charlson, M. E. (1998). The mortality of elder mistreatment. JAMA, 280(5), 428-432. https://doi.org/10.1001/jama.280.5.428

Lafferty, A., Treacy, M.P., Fealy, G., Drennan, J. \& Lyons, I. (2012). Older People's Experiences of Mistreatment and Abuse. National Centre for the Protection of Older People (NCPOP) UCD School of Nursing, Midwifery and Heath Systems, Dublin, Ireland.

Lafortune, A. (2014). "What Is the Family Impact on Early Childhood Development?", available at: https://www.livestrong.com/article/267910-what-is-the-family-impact-onearly-childhooddevelopment/ (accessed 02 December 2017).

Lai, D. W., \& Chau, S. B. (2007). Predictors of health service barriers for older Chinese immigrants in Canada. Health and Social Work, 32(1), 57-65. https://doi.org/10.1093/hsw/32.1.57 
Lai, D. W. (2004). Health status of older Chinese in Canada. Canadian Journal of Public Health, 95(3), 193-197. https://doi.org/10.1007/BF03403647

Lai, W. L., Daoust, G. D., \& Li, L. (2014). Understanding elder abuse and neglect in aging Chinese immigrants in Canada. The Journal of Adult Protection, 16(5), 322-334.

Lee, H. Y., \& Eaton, C. K. (2009). Financial abuse in elderly Korean immigrants: Mixed analysis of the role of culture on perception and help-seeking intention. Journal of Gerontological Social Work, 52(5), 463-488. https://doi.org/10.1080/01634370902983138

Leisey, M., Kupstas, P. K., \& Cooper, A. (2009). Domestic Violence in the Second Half of Life. Journal of Elder Abuse \& Neglect, 21(2), 141-155. https://doi.org/10.1080/08946560902779951

Levine, C. (1998). Rough crossings: Family caregivers' odysseys through the health care system. United Hospital Fund of New York.

Levine, C., Reinhard, S. C., \& Feinburg, L. F. (2003). Family caregivers on the job: Moving beyond ADLs and IADLs. Generations, 27(4), 17-23.

Margaret, B. B. A. (1997). Family Dynamics. Activities, Adaptation and Aging, 2(24), 65-72. https:// doi.org/10.1300/J016v22n04_07

Marsh, H. W., Guo, J., Dicke, T., Parker, P. D., \& Craven, R. G. (2020). Confirmatory factor analysis (CFA), exploratory structural equation modeling (ESEM), and set-ESEM: Optimal balance between goodness of fit and parsimony. Multivariate Behavioral Research, 55(1), 102-119. https://doi.org/10.1080/00273171.2019.1602503

Matthiessen, C. (2017). "Family conflicts", available at: https://www.caring.com/articles/family-conflict (accessed 14 November 2017).

Mezey, N. J., Post, L. A., \& Maxwell, C. D. (2002). Redefining intimate partner violence: Women's experiences with physical violence and non-physical abuse by age. International Journal of Sociology and Social Policy, 22(7/8), 122-154. https://doi.org/10.1108/01443330210790120

Miller, L.S. (2003). "Caregiver Cognitive Impairment and Quality of Elder Care”, Symposium Paper Presented at the Annual Conference of the Gerontological Society of America, San Diego, CA.

Miller, L. S., Lewis, M. S., \& Williamson, G. M. (2006). Caregiver cognitive status and potentially harmful caregiver behavior. Aging Mental Health, 10(2), 125-133. https://doi.org/10.1080/ 13607860500310500

Moos, R. H., Brennan, P. L., Schutte, K. K., \& Moos, B. S. (2006). Older adults coping with negative life events: Common processes of managing health, interpersonal and financial/work stressors. International Journal of Aging \& Human Development, 62(1), 39-59. https://doi.org/10.2190/ ENLH-WAA2-AX8J-WRT1

Mouton, C. P., Larme, A. C., Alford, C. L., Talamantes, M. A., McCorkle, R. J., \& Burge, S. K. (2005). Multiethnic perspectives on elder mistreatment. Journal of Elder Abuse and Neglect, 17(2), 21-44. https://doi.org/10.1300/J084v17n02_02

Muijeen, K., Kongvattananon, P., \& Somprasert, C. (2020). The key success factors in focus group discussions with the elderly for novice researchers: A review. Journal of Health Research, 34(4), 359-371. https://doi.org/10.1108/JHR-05-2019-0114

Murrell, S. A., Norris, F. H., \& Hutchins, G. L. (1984). Distribution and desirability of life events in older adults: Population and policy implications. Journal of Community Psychology, 12(4), 301-311. https://doi.org/10.1002/1520-6629(198410)12:4\%3c301::AID-JCOP2290120403\%3e3.0.CO;2-I

National Crime Record Bureau. (2010). "Crime in India Report (2001-2010)", New Delhi. 105. National Crime Records Bureau (2014) Crime in India. Ministry of Home Affairs, Government of India, East Block-7, R.K. Puram, New Delhi. http://ncrb.gov.in

National Research Council. (2003). Elder Mistreatment: Abuse, Neglect, and Exploitation in an Aging America. National Academies Press (US) https://www.ncbi.nlm.nih.gov/books/NBK98799/

Naughton, C., Drennan, J., Treacy, M. P., Lafferty, A., Lyons, I., Phelan, A., et al. (2010). Abuse and neglect of older people in Ireland - Report on the national study of elder abuse and neglect. Dublin: NCPOP.

Naughton, L., Padeiro, M., \& Santana, P. (2021). The twin faces of ageism, glorification and abjection: A content analysis of age advocacy in the midst of the COVID-19 pandemic. Journal of Aging Studies, 57, 100938. https://doi.org/10.1016/j.jaging.2021.100938

Nelson, T. D. (2005). Ageism: Prejudice against out feared future self. Journal of Social Issues, 61(2), 207-221. https://doi.org/10.1111/j.1540-4560.2005.00402.x

Nisha, C., Manjaly, S., Kiran, P., Mathew, B., \& Kasturi, A. (2016). Study on elder abuse and neglect among patients in a medical college hospital, Bangalore, India. Journal of Elder Abuse \& Neglect, 28(1), 34-40. https://doi.org/10.1080/08946566.2015.1113599 
O'Leary, K. D. (1999). Psychological abuse: A variable deserving critical attention in domestic violence. Violence and Victims, 14(1), 3-23. https://doi.org/10.1891/0886-6708.14.1.3

Patel, V. K., Tiwari, D. S., Shah, V. R., Patel, M. G., Raja, H. H., \& Patel, D. S. (2018). Prevalence and predictors of abuse in elderly patients with depression at a tertiary care centre in Saurashtra. India. Indian Journal of Psychological Medicine, 40(6), 528-533. https://doi.org/10.4103/IJPSYM.IJPSYM_18_18

Paul, \& Perkins, P.A. (2017). Physical Abuse. Nursing home abuse guide, available at: http:// nursinghomeabuseguide.com/elder-abuse/physical-abuse/ (accessed 14 November 2017).

Payne, B.K. (2013). Physical and Emotional Abuse of the Elderly. Problem-Oriented Guides for Police Problem-Specific Guides Series Guide No. 71, Office of Community Oriented Policing Services, U.S. Department of Justice, available at: www.cops.usdoj.gov

Pelotti, S., D’Antone, E., Ventrucci, C., Mazzotti, M. C., Salsi, G., Dormi, A., \& Ingravallo, F. (2013). Recognition of elder abuse by Italian nurses and nursing students: evaluation by the Caregiving Scenario Questionnaire. Aging clinical and experimental research, 25(6), 685-90 685-690 https:// doi.org/10.1007/s40520-013-0087-9

Pettee, E.J. (1997). Elder abuse: Implications for staff development. Journal of Nursing Staff Development, 12(1), 7-12. https://europepmc.org/article/med/9110711

Phelan, A., \& Ayalon, L. (2020). The Intersection of Ageism and Elder Abuse. In Advances in Elder Abuse Research (pp. 11-22). Springer, Cham. https://doi.org/10.1007/978-3-030-25093-5_2

Pillemer, K., \& Finkelhor, D. (1988). Abuse of patients in nursing homes: Findings from a survey of staff. The Gerontologist, 29(3), 314-320. https://doi.org/10.1093/geront/29.3.314

Pillemer, K., \& Suitor, J. J. (1992). Violence and violent feelings: What causes them among family caregivers? Journal of Gerontology, 47(4), S165-S172. https://doi.org/10.1093/geronj/ 47.4.S165

Podnieks, E. (2008). Elder abuse: The Canadian experience. Journal of Elder Abuse and Neglect, 20(2), 126-150. https://doi.org/10.1080/08946560801974612

Quinn, M. J., \& Tomito, S. K. (1986). Elder abuse and neglect: Causes, diagnosis and intervention strategies. Springer.

Ramsey, K. H., Teaster, P., Mendiondo, M., Abner, E., Cecil, K., \& Tooms, M. (2007). Sexual abuse of vulnerable adults in care facilities: Clinical findings and a research initiative. Journal of the American Psychiatric Nurses Association, 12(6), 332-339. https://doi.org/10.1177/1078390306298576

Rashmi, A., Sequeira, L., \& Kumar, P. S. (2020). Elder Abuse in Indian Setting-A Misconception or a Reality-A Deductive Analysis. Indian Journal of Public Health Research \& Development, 11(1), 31-34. https://doi.org/10.37506/ijphrd.v11i1.317

Reinhard, S.C., Given, B., Petlick, N.H. \& Bemis, A. (2008). Supporting Family Caregivers in Providing Care. In: Patient Safety and Quality: An Evidence-Based Handbook for Nurses, Rockville (MD), Agency for Healthcare Research and Quality (US), Chapter 14, Available at: https://www.ncbi.nlm. nih.gov/books/NBK2665/ (accessed 14 November 2017).

Salarvand, S. H., Abedi, H., \& Shamlu, K. (2007). The feeling of powerlessness in older people living in nursing homes. Iran Journal of Nursing, 20(50), 61-69. http://ijn.iums.ac.ir/article-1-307-en.html

Scherbring, M. (2002). Effect of caregiver perception of preparedness on burden in an oncology population. Oncology Nursing Forum, 29(6), 70-76. https://doi.org/10.1188/02.onf.e70-e76

Schumacher, K. L., Stewart, B. J., Archbold, P. G., Dodd, M. J., \& Dibble, S. L. (2000). Family caregiving skill: Development of the concept. Research in Nursing \& Health, 23(3), 191-203. https://doi.org/10. 1002/1098-240X(200006)23:3\%3c191::AID-NUR3\%3e3.0.CO;2-B

Schumacher, K.L., Jones, P.S., \& Meleis, A.I. (1999). Helping Elderly Persons in Transition: A Framework for Research and Practice. Available at: http://repository.upenn.edu/nrs/10.

Schumacker, R. E., \& Lomax, R. G. (2004). A beginner's guide to structural equation modeling. Psychology press.

Senior Rights. (2020). "Psychological \& Emotional Abuse" Available at: https://seniorsrights.org.au/yourrights/psychological-emotionalabuse/\#: :text=Psychological $\% 20$ and $\% 20$ emotional $\% 20$ abuse $\%$ 20is, Verbal\% 20assaults \& text $=$ Other $\% 20$ abusive $\% 20$ behaviours $\% 20$ which $\% 20$ result $\% 20 \mathrm{in} \%$ 20emotional\%20or\%20psychological\%20distress (Accessed on 15 July 2020).

Seth, N., Yadav, A., Adichwal, N. K., \& Kamble, S. B. (2019). Elder abuse and its association with sociodemographic variables in India. Clinical Epidemiology and Global Health, 7(2), 188-191. https://doi. org/10.1016/j.cegh.2018.05.002

Sheridan, K. (2016). “Appeals Court Overturns State's Denial of Nursing Home Resident's Request for Motorized Wheelchair", In Special Needs News, available at: https://www.oceancountyelderlaw.com/ 
appeals-court-overturns-states-denial-of-nursinghome-residents-request-for-motorized-wheelchair/ (accessed on 11 November 2017).

Shim, W. S., \& Nelson-Becker, H. (2009). Korean older intimate partner violence survivors in North America: Cultural considerations and practice recommendations. Journal of Women and Aging, 21(3), 213228. https://doi.org/10.1080/08952840903054773

Silver, H. J., Wellman, N. S., \& Arnold, D. J. (2004). Older adults receiving home enteral nutrition: Enteral regimen, provider involvement, and health care outcomes. Journal Parenter Enteral Nutr, 28(2), 92-98. https://doi.org/10.2307/2137031

Singer C. (2018). "Health effects of social isolation and loneliness", J Aging Life Care. Spring 2018. Aging Life Care Association. Available at: https://www.aginglifecarejournal.org/health-effects-of-social-isolationand-loneliness/ (Accessed on 10 June 2021).

Smith, \& King, J. (2002), "Caring for Aging Loved Ones”, Tyndale House Publishers.

Spencer, B. (2016), "What's the best way to keep a parent with Alzheimer's safe from wandering at night?", available at: https://www.caring.com/questions/lock-alzheimersparent-in-their-room (accessed 16 November 2017).

Spillman, B. C., \& Pezzin, L. E. (2000). Potential and active family caregivers: Changing networks and the 'sandwich generation.' The Milbank Quarterly, 78(3), 347-374. https://doi.org/10.1111/1468-0009. 00177

Talpur, A. A., Ryan, T., Ali, P., \& Hinchliff, S. (2018). Elder mistreatment in South Asian communities: A review of the literature. The Journal of Adult Protection, 20(5/6), 193-206. https://doi.org/10.1108/ JAP-06-2018-0011

Tatara, T. (1990). Elder abuse in the United States: An issue paper. National Aging Resource Center.

Taylor, B. J., \& Donnelly, M. (2006). Professional perspectives on decision making about the long-term care of older people. British Journal Social Work, 36(5), 807-826. https://doi.org/10.1093/bjsw/bch322

Tewari, A. (2009), "The old age crisis in India", available at: https://www.youthkiawaaz.com/2009/07/old-ageproblems-india/ (accessed 09 November 2017).

Travis, S. S., Bethea, L. S., \& Winn, P. (2000). Medication administration hassles reported by family caregivers of dependent elderly persons. The Journals of Gerontology Series a: Biological Sciences and Medical Sciences, 55(7), M412-M417. https://doi.org/10.1093/gerona/55.7.M412

Traxler, C. (2017). "Emotional Abuse", Nursing home abuse center, available at: https://www.nursinghom eabusecenter.com/elder-abuse/types/emotional-abuse/ (accessed 06 November 2017).

US Congress. (1990). Elder Abuse: Curbing a National Epidemic: Hearing Before the House Select Committee on Aging, 101st Congress, 2nd Session, Cleveland, Ohio, December 10, 1990.

Vardhan, R. (2017). Elder abuse and elder victimization: A sociological analysis. International Annals of Criminology, 55(1), 99-113. https://doi.org/10.1017/cri.2017.7

Wang, J. J., Lin, J. N., \& Lee, F. P. (2006). Psychological abusive behavior by those caring for the elderly in a domestic on text. Geriatric Nursing, 27(5), 284-291. https://doi.org/10.1108/JAP-03-2014-0006

Weeks, L., Dupuis-Blanchard, S., Arseneault, R., MacQuarrie, C., Gagnon, D., \& LeBlanc, G. M. (2018). Exploring gender and elder abuse from the perspective of professionals. Journal of Elder Abuse \& Neglect, 30(2), 127-143. https://doi.org/10.1080/08946566.2017.1388756

Wheeler, R.B. (2010). "How Will the Longevity Boom Impact Our World?", available at: https://www. everydayhealth.com/longevity/longevity-boom-and-its-impact.aspx (accessed 09 November 2017).

WHO. (2002). World Report on Violence and Health in 2002. World Health Organization.

WHO. (2011). European Report on Preventing Elder Maltreatment. World Health Organization.

WHO. (2021). "Elder abuse" Available at: https://www.who.int/news-room/factsheets/detail/elder-abuse (Accessed on 12 June 2021).

Wiktorowicz, J. (2017). Competencies as a factor of economic deactivation: Application of exploratory factor analysis. International Journal of Social Economics, 44(5), 605-619. https://doi.org/10.1108/ IJSE-08-2015-0198

Wilkinson, J.M. (2005). "Prentice Hall nursing diagnosis handbook with NIC interventions and NOC outcomes. (8th ed.)", Upper Saddle River, NJ: Pearson Education.

Williamson, G.M., \& Shaffer, D.R. (2001). The Family Relationships in Late Life Project. Relationship quality and potentially harmful behaviors by spousal caregivers: How we were then, how we are now. Psychology and aging, 16(2), 217-226.

Wolf, R. S. (1988). Elder abuse: Ten years later. Journal of the American Geriatrics Society, 36(8), 758-762. https://doi.org/10.1111/j.1532-5415.1988.tb07187.x

World Health Organisation. (2018). Ageing and health. https://www.who.int/newsroom/ fact-sheets/detail/ ageing-and-health. Retrieved on 22 Aug 2020, 05:34 PM. 
World Health Organization (WHO). (1999). "Health 21: Health Policy - Framework, for all for the European Region of WHO", European Series of Health for all, No. 6 Copenhagen: Bereau Regional the Europe, WHO

World Health Organization. (2002). The Toronto declaration on the global prevention of elder abuse. WHO.

Yan, E., \& Kwok, T. (2011). Abuse of older Chinese with dementia by family caregivers: An inquiry into the role of caregiving burden. International Journal of Geriatric Psychiatry, 26(5), 527-535. https://doi. org/10.1002/gps. 2561

Yllo, K. A. (2005). Through a feminist lens: Gender, diversity and violence-extending the feminist framework. In D. R. Loseke, R. J. Gelles, \& M. M. Cavanagh (Eds.), Current controversies in family violence (pp. 19-34). Sage.

Publisher's Note Springer Nature remains neutral with regard to jurisdictional claims in published maps and institutional affiliations.

Naval Bajpai is an avid analyst of contemporary trends in marketing, human resource management and entrepreneurship development. He authored scores of research papers and books entitled such as Business Statistics, Business Research Methods and Marketing Research published by Pearson Education, India.

Kushagra Kulshreshtha is an Associate Professor at Institute of Business Management, GLA University, Mathura, India. His research work has been published in various national/international journals of repute such as Elsevier, Taylor \& Francis, Emerald, Sage and Inderscience. He has been a reviewer for many reputed international journals. His areas of interest are corporate strategy, consumer behaviour, elder abuse, technology acceptance models and conjoint analysis. He studies the behaviour of youth, elderly people and their consumer preferences, including the role of brand, price, technology and sustainability during the purchasing decision.

Prince Dubey has a rich experience of teaching to post-graduate courses in management. His research work is published in various national/international journals and conferences.

Gunjan Sharma is an Assistant Professor at Institute of Business Management, GLA University, Mathura. She has authored several research papers for national and international journals of repute such as Emerald and Inderscience. Her areas of interest are behavioral finance, financial inclusion, investor sentiments, consumer behaviour, elder abuse, technology adoption models, conjoint analysis and banking. 